\title{
A RE-EXAMINATION OF CALANUS COLLECTED OFF PLYMOUTH
}

\author{
By F. S. Russell, F.R.S. \\ Director of the Plymouth Laboratory
}

Rees (I949) has established significant biological differences between the two forms of the copepod Calanus finmarchicus, namely finmarchicus and helgolandicus. It is therefore necessary that in future research on the behaviour of Calanus the two forms should be distinguished.

I have myself published observations on the vertical distribution of Calanus and on the seasonal changes in size of individuals of the populations of this copepod off Plymouth. In order to know whether my results have been vitiated by the presence of the two forms in the collections, I have re-examined representative samples of adult females, using the fifth leg as the distinguishing character. The collections in question were those made in 1926 which formed the subject of a paper on seasonal changes in vertical distribution and in the sizes of individuals of different generations (Russell, I928); and those made in I93I and recorded in my paper on the vertical distribution of Calanus in relation to light intensity (Russell, I934).

From the collections made between April and September 1926, twelve samples amounting to 240 individuals were examined. Among these, eight specimens were finmarchicus, the remainder being helgolandicus. The form finmarchicus only occurred in the months April, May and June, the maximum number in any one sample being 10 \%. Over 300 specimens were examined from the collections made in July and August I93I; all were helgolandicus.

I have also examined over 200 specimens scattered through the collections made in 1930 on which the results reported by Bogorov (I934) on seasonal changes in biomass were based. Again helgolandicus was found to be similarly predominant. The very large catch recorded on I5 May I930 (Russell, I933) contained $4 \%$ finmarchicus.

It is thus clear that these published results can be regarded as representative of helgolandicus, and the vertical distribution and seasonal changes refer to that form. It is interesting to record that the only specimens of finmarchicus occurring in May, in 1926 and 1930, were much smaller than the helgolandicus which attained their greatest size in that month. Rees (1949) similarly found finmarchicus to be smaller than helgolandicus in the North Sea.

I am grateful to Dr C. B. Rees for confirmation of some of my identifications. 


\section{SUMMARY}

A re-examination of some collections of the copepod Calanus finmarchicus made off Plymouth has shown that the conclusions reported in the following publications can be regarded as referring to the form helgolandicus.

\section{REFERENCES}

Bogorov, B. G., I934. Seasonal changes in biomass of Calamus finmarchicus in the Plymouth area in 1930. Fourn. Mar. Biol. Assoc., Vol. 19, pp. 585-612.

REES, C. B., I949. Continuous plankton records : the distribution of Calanus finmarchicus (Gunn.) and its two forms in the North Sea, 1938-39. Hull. Bull. Mar. Ecol., No. I4, Vol. 2, pp. 215-75.

RusSELL, F. S., I928. The vertical distribution of marine macroplankton. VII. Observations on the behaviour of Calanus finmarchicus. Fourn. Mar. Biol. Assoc., Vol. I5, pp. 429-54.

- 1933. The seasonal distribution of macroplankton as shown by catches in the 2-metre stramin ring-trawl in off-shore waters off Plymouth. Fourn. Mar. Biol. Assoc., Vol. 19, pp. 73-8I.

1934. The vertical distribution of marine macroplankton. XII. Some observations on the vertical distribution of Calanus finmarchicus in relation to light intensity. Fourn. Mar. Biol. Assoc., Vol. 19, pp. 569-84. 